\title{
- Transesophageal echocardiographic follow-up of patients implanted with left atrial appendage occluder Amplatzer Amulet
}

\section{Branimir Bukša*, \\ Ante Anić, \\ Zorislav Šušak}

Zadar General Hospital, Zadar, Croatia
RECEIVED:

March 11, 2017

ACCEPTED:

April 6, 2017

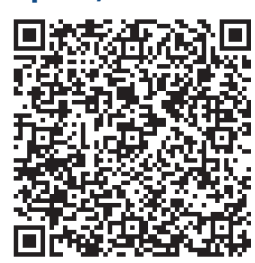

KEYWORDS: atrial appendage, occluder device Amplatzer Amulet, transesophageal echocardiography, atrial fibrillation, stroke.

CITATION: Cardiol Croat. 2017;12(4):132. | https://doi.org/10.15836/ccar2017.132

*ADDRESS FOR CORRESPONDENCE: Branimir Bukša, Opća bolnica Zadar, Bože Peričića 5, HR-23000 Zadar, Croatia. / Phone: +385-23-505-292 / E-mail: brarbuk@gmail.com

ORCID: Branimir Bukša, http://orcid.org/0000-0001-5206-512X • Ante Anić, http://orcid.org/0000-0002-6864-3999 Zorislav Šušak, http://orcid.org/0000-0003-2977-6833

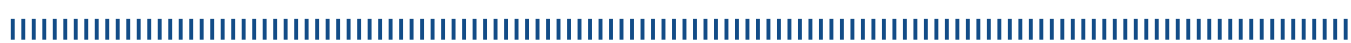

The Amplatzer ${ }^{\mathrm{TM}}$ Amulet ${ }^{\mathrm{TM}}$ (St. Jude Medical) is a second generation Amplatzer ${ }^{\mathrm{TM}}$ Cardiac Plug device for left atrial appendage closure for stroke prevention in patients with atrial fibrillation. Second generation device features improved device stability, theoretically may reduce thrombus formation on atrial side and accommodates larger left atrial appendages. Transesophageal echocardiography in follow-up of patients implanted with left atrial appendage occluder Amplatzer ${ }^{\mathrm{TM}}$ Amulet ${ }^{\mathrm{TM}}$ is usually performed at 6 weeks' post implantation. Imaging at that time point is performed to verify absence of left atrial or device-related thrombus, to assess the device position and to evaluate completeness of sealing (residual flow). Short-term follow-up are available in literature showing high success rate and excellent sealing ${ }^{1-3}$ and in that context we present our uneventful 6 month follow up experience.

1. Lam SC, Bertog S, Gafoor S, Vaskelyte L, Boehm P, Ho RW, et al. Left atrial appendage closure using the Amulet device: an initial experience with the second generation amplatzer cardiac plug. Catheter Cardiovasc Interv. 2015 Feb 1;85(2):297-303. https://doi.org/10.1002/ccd.25644

2. Cruz-González I, Arzamendi D, Rama-Merchan JC, Piña-González P, Sánchez PL, Serra A. Left Atrial Appendage Occlusion With the New Amulet'TM Device: Feasibility, Safety and Short-term Efficacy. Rev Esp Cardiol (Engl Ed). 2015 Aug;68(8):724-6. https://doi.org/10.1016/j.rec.2015.03.011

3. Kleinecke C, Park JW, Gödde M, ZintI K, Schnupp S, Brachmann J. Twelve-month follow-up of left atrial appendage occlusion with Amplatzer Amulet. Cardiol J. 2017 Feb 15. https://doi.org/10.5603/CJ.a2017.0017 [Epub ahead of print] 